\title{
DISCRIMINATION OF LESS AND HIGH FRACTIONATED GRANITIC ROCKS, BY WEATHERING SCHEME, BIRIRIG AREA, CENTRAL EASTERN DESERT, EGYPT.
}

\author{
Salem, A. K., Shalaby, B. N., Abdel Wahab, W. and Ismail, A. I. M. \\ Geological Sciences Department, National Research Centre, P.O. 12622, 33 El Bohooth St. Dokki, Giza, \\ Egypt.
}

\begin{abstract}
The granitic rocks in Egypt cover more than $40 \%$ of the total area of the basement rocks, many efforts were exerted aiming to classify the granitic rocks in Egypt. The present work classifies the Biririg granitic rocks, in the central Eastern Desert of Egypt, on the basis of their mineralogical and chemical composition and discusses the effects of different grades of weathering on their mineralogical and geochemical characteristic. Geochemically, the Biririg granitic rocks (BGR) were derived from calc-alkaline peraluminous parental melts as revealed from agpaitic index, modified alkali-lime index and the aluminum saturation index.

Based on geochemical characteristic, the BGR are classified into less fractionated pinkish white granite (LFG) mainly hornblende biotite granite, and highly fractionated pink granite (HFG) mainly biotite granite, the later is evolved, through fractional crystallization from more basic and calcic melts. The BGR were evolved at active continental margin regime, as the geochemical characteristics of the BGR exhibit three main sources of enrichments namely subduction zone, convicted mantle wedge and sub-continental lithosphere.

This research discusses, further, the relation between grade of weathering and engineering-pathological properties of the granitic rocks exposed in Biririg area. The chemical index of alteration (CIA) values revealed that, both of LFG and HFG are low weathered, with slight increase of weathering towards the less fractionated pinkish white granite.

The pinkish white granite is more basic than pink granite, as the former exhibits more mafic constituents represent about $8 \%$ of the total rock volume and are mainly biotite with less frequent amounts of hornblende. The BGR were classified into WI and WII according to the grade of weathering, where the mineralogical, chemical and engineering properties changed. Most elements redistribute in their newly formed secondary minerals. The differences observed in the composition of the WII samples relative to the slightly weathered WI ones, could be attributed to the fractional crystallization of melt, original magmatic features and/or crustal contamination.
\end{abstract}

Keywords: Biririg Granite, Geochemistry, Orogenic granites, Grade of weathering, Weathering scheme

\section{INTRODUCTION}

The granitic rocks in Egypt cover about $42.9 \%$ of the total area of the basement rocks, (Older Granites: $26.7 \%$ and Younger granites: $16.2 \%$; Stern, 1979). Many efforts were exerted aiming to classify the granitic rocks in Egypt, some of them classified these rocks based on their age in terms of; Younger and Older Granites, and others according to their colours in terms of Grey, Pink and Red Granites. Lately, these rocks are classified according to the orogeny or tectonic settings from which they were derived, e.g. Syn-orogenic granite, Late orogenic granite and Post orogenic granite.

The granitic rocks in Egypt are classified according to their ages into Older Granite and Younger Granite according to El-Ramly, 1972; El-Gaby, 1975; Hashad, 1980; Hussein et al., 1982; El-Gaby et al., 1988; and Hassan and Hashad, 1990. The age of the Older Granites (granitoids) is 850-630 Ma, according to Hassan and Hashad (1990), they are calc alkaline and mesozonal, Stern et al., (1984), Syn-orogenic, (El Shazely, 1964) and Syn-tectonic, (Sabet, 1972). The age of the Younger Granite is 620-530 Ma, (Hassan and Hashad 
1990), they are epizonal, (Stern et al., 1984), Late orogenic, (El Shazely, 1964), Late to Post tectonic, (El Ramly, 1972). Hussein et al. (1982), classified the Younger Granites into; suture related (G2-granite) which is formed in post-orogenic regimes and intraplate (G3-granite) which is rifting related. Hassan and Hashad (1990) proposed the parental magma of the Younger Granites to be derived at three possible tectonic regimes, namely; volcanic arcs i.e. subduction related; arc-continent collisions and within continental plates.

The studied area is located in the Central Eastern Desert of Egypt, between Lat. $25^{\circ} 20^{\prime}$ and $25^{\circ} 25^{\prime} \mathrm{N}$ and Long. $34^{\circ} 20^{\prime}$ and $34^{\circ} 25^{\prime}$ E. Stratigraphically, the present granitic rocks represent the youngest unit in the area, according to (Akaad and El-Ramly, 1960, El-Ramly et al.,1993 and Salem et al., 1995), occupying the central and southern parts of the area and are subdivided into pink granites and pinkish white granites. Metagabbros and granodiorites crop out in the northern part, exhibiting sharp contacts with the younger granitic rocks, while the metasediments occupy the low hills in southern and southwestern parts, Fig. 1.

Weathering processes creates variable changes in the mineralogical constituents, physical, mechanical and chemical properties of rocks and this would be assessed in quantitative rather than qualitative terms $(+)$. The determination of weathering degree by a simple and reliable way is still open to development (Gokceoglu et al., 2009), where different researches have gained the rate of weathering for examples: (Onodera et al., 1974; Cole and Sandy, 1980; Hencher and Martin, 1982; Guolin and Yushan, 1990; Kilic, 1995; Gokceoglu and Aksoy, 2000; Gupta and Rao, 2001; Lan et al., 2003; Arikan, et al., 2007).

Weathering could be estimated as qualitative or quantitative. The qualitative classification scheme is based on the observed characters, such as color change (Lee, 1987), chemical alteration of feldspars or biotites (Hencher and Martin, 1982; Irfan and Powell, 1985; Raj, 1985; Lee, 1987), and mechanical changes (ISRM, 1981; Hencher and Martin, 1982; Dearman, 1995). On the other hand, quantitative classification leads to reliable and objective method more than qualitative approaches (Irfan, 1996). Quantitative classification approaches may reflect on mineralogical, chemical and index properties. Varieties of mineralogical indices have been planned (Onodera et al., 1974; Irfan and Dearman, 1978a, b; Cole and Sandy, 1980; Tuğrul and Gurpınar, 1997; Sousa et al., 2005; Ceryan, et al., 2008).

Fig. 1: Geological map of Biririg area (Akaad and El-Ramly, 1960).

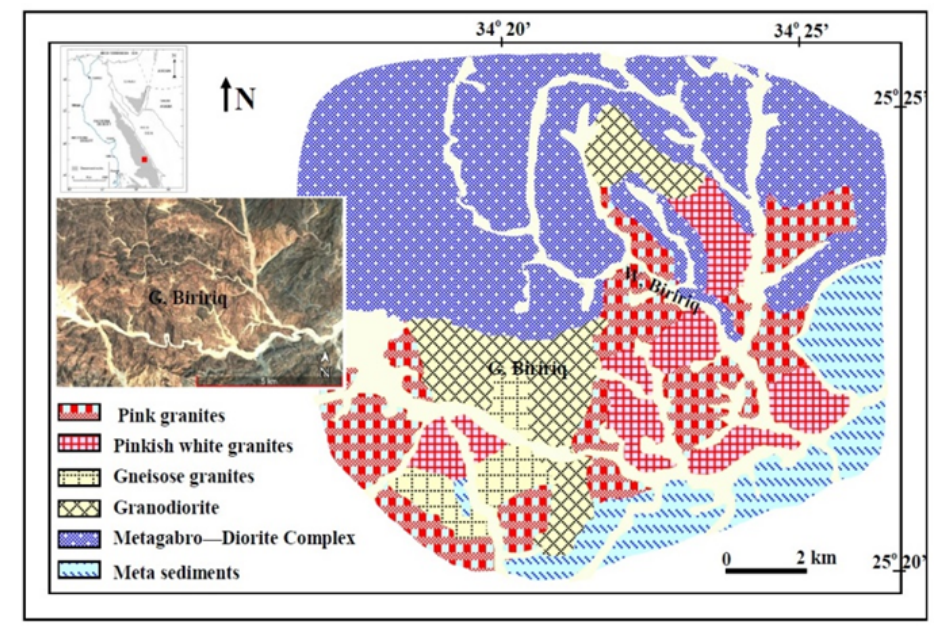

The present study aims to reveal the tectonic setting of the (BGR) as well as to record the changes in geochemical characteristics of different types of less and highly fractionated granitic rock masses due to weathering process.

\section{Materials and methods}

Representative granitic samples from Biririg area were collected and prepared for petrographic investigation. Based on petrographic investigation, thirteen granitic samples were prepared for major oxides and trace elements chemical analyses, by using XRF technique. The powdered rock samples were prepared in two forms, fused beads for the major elements and pressed powder for trace element determinations. The 
Discrimination of less and high fractionated granitic rocks

analyses were carried out at the National Research Centre (NRC), Cairo using XRF Wavelength Dispersive Spectrometer (Axios Advanced, PANalytical 2005). Major element data were obtained and processed through advanced data treatment software (Ominion). For the trace and some REEs, the PRO-TRACE package with the multi-element synthetic standards prepared by BGS/ PANalytical Corporation was used. Loss on ignition (LOI) was obtained based on (Heiri et al., 2001) test method for the LOI of solid combustion. Subsamples are placed in pre-ignited weighed crucibles and weighed after heating overnight at $100^{\circ} \mathrm{C}$ to remove humidity using a drying oven. A Scientific Isotemp Muffle Furnace is used for the igniting step. Weight loss is measured after igniting at $1000^{\circ} \mathrm{C}$ for $2 \mathrm{~h}$ to remove volatile substances.

\section{RESULTS AND DISCUSSION}

\section{Petrography}

The studied Biririg granitic rocks (BGR) are medium to coarse grained, buff to pinkish red in colour. They are composed mainly of quartz, sodic plagioclase, potash feldspar, mainly orthoclase with less frequent amounts of microcline. The mafic minerals are mainly biotite and/or hornblende.

Petrographically, the studied rocks are classified into two main groups; biotite granite and hornblende biotite granite. The later is more basic, as the mafic constituents represent about $8 \%$ of the total rock volume and are mainly biotite with less frequent amounts of hornblende, Fig. (2A), the feldspars constitute more than $50 \%$ of the total rock volume; plagioclase (ca. 40\%) and orthoclase (ca. 15\%). The more acidic biotite granites group, comprises feldspars (ca. 65\%) of the total rock volume, (plagioclase $=40 \%$ and $\mathrm{K}$-feldspars $=$ $25 \%$ ); the K-feldspars are mainly orthoclase (Fig. 2B), with subordinate amounts of microcline. The total mafic content is less than 5\% and is represented mainly by biotite (Fig. 2C). Quartz, in the both groups, forms about $30 \%$ of the rock volume, in the form of rounded to sub-rounded crystals. Sometimes quartz enclosed within the feldspar crystals in a graphic pattern, Fig. (2D). Sphene, apatite and iron oxides recorded in the both groups as accessory minerals.

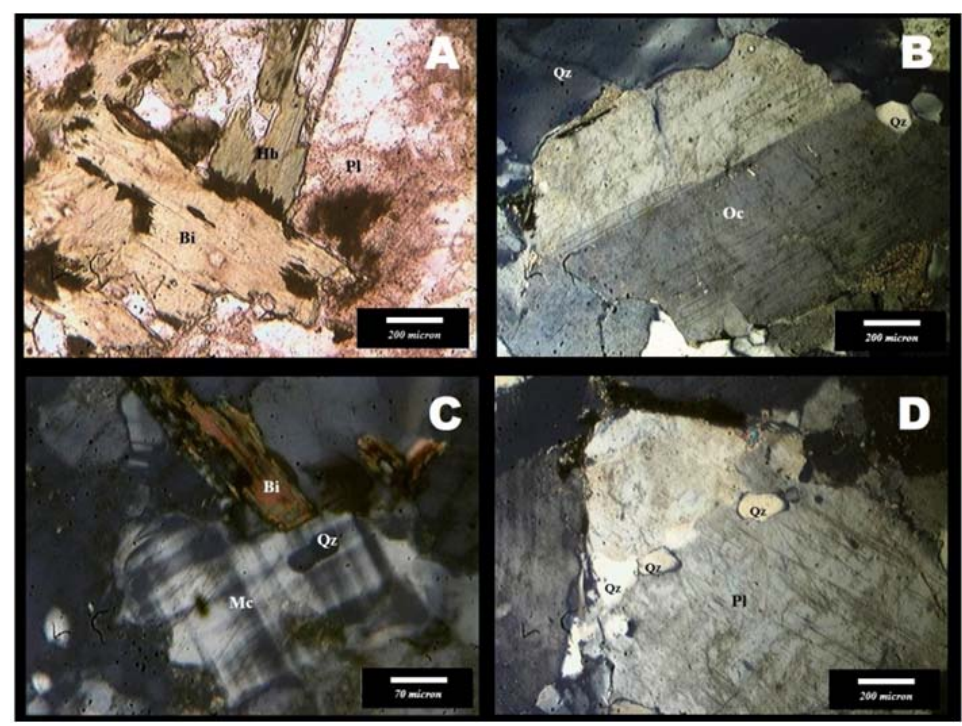

Fig. 2: Photomicrographs in: A) Biotite hornblende granite, showing biotite crystal (Bi) enclosing iron oxides, and intersects hornblende crystal $(\mathrm{Hb})$, partially altered to chlorite. Both crystals are surrounded by plagioclase. (P. P.). B) Biotite granite showing simply twinned orthoclase $(\mathrm{Oc})$ attacked and corroded by the surrounding quartz crystals (Qz). (C. N.). C) Bbiotite granite showing crosshatched microcline (Mc) enclosing quartz (Qz) and intersecting biotite lath (Bi). The groundmass is occupied by quartz crystals. (C. N.). D) Biotite hornblende granite, showing rounded quartz crystals $(\mathrm{Qz})$ enclosed in plagioclase megacryst in graphic pattern. (C. N.)

\section{Geochemical Characteristics}

The studied granitic rocks display silica content ranges from $69.00 \%$ to $74.84 \%$, Table 1 . Based on feldspar composition, the Biririg granitic rocks (BGR) could be differentiated into two main types; less fractionated granites (LFG) having average feldspar content $\mathrm{Ab}_{60.53}$ An19.19 Or20.28, and highly fractionated granites (HFG) of feldspar content $\mathrm{Ab}_{57.26} \mathrm{An} 9.39 \mathrm{Or}_{36.35}$, (Table 1). Pyroxene is the main normative mafic mineral, with averages of $3.68 \%$ and $1.61 \%$ in LFG and HFG, respectively.

The BGR exhibited a leucocratic nature as indicated from the differentiation index (D.I.) of (Thronton and Tuttle, 1960); the differentiation index ranges from 76.74 to 82.00 in LFG and from 85.60 to 94.29 in HFG. 
Salem, et al

Table 1, Chemical analyses, CIPW norm and some calculated indices for the studied BGR

\begin{tabular}{|c|c|c|c|c|c|c|c|c|c|c|c|c|c|c|c|}
\hline & \multicolumn{6}{|c|}{ Less fractionated granite } & \multicolumn{9}{|c|}{ Highly fractionated granite } \\
\hline & 1 & 2 & 3 & 4 & 5 & Average & 6 & 7 & 8 & 9 & 10 & 11 & 12 & 13 & Average \\
\hline $\mathrm{SiO}_{2}$ & 69.00 & 69.00 & 69.41 & 71.02 & 72.47 & 70.18 & 71.47 & 71.50 & 72.11 & 73.06 & 73.46 & 73.57 & 73.88 & 74.84 & 72.99 \\
\hline $\mathrm{Al}_{2} \mathrm{O}_{3}$ & 15.77 & 16.47 & 16.75 & 14.75 & 15.23 & 15.79 & 14.96 & 14.83 & 14.99 & 14.84 & 15.10 & 14.66 & 15.55 & 14.41 & 14.92 \\
\hline $\mathrm{Fe}_{2} \mathrm{O}_{3}$ * & 3.41 & 2.42 & 2.19 & 2.88 & 1.97 & 2.57 & 2.37 & 2.11 & 1.77 & 1.14 & 0.78 & 1.31 & 0.51 & 1.09 & 1.39 \\
\hline $\mathrm{MnO}$ & 0.06 & 0.08 & 0.04 & 0.07 & 0.04 & 0.06 & 0.07 & 0.06 & 0.05 & 0.12 & 0.02 & 0.04 & 0.02 & 0.03 & 0.05 \\
\hline $\mathrm{MgO}$ & 1.25 & 1.19 & 1.07 & 0.95 & 0.94 & 1.08 & 0.76 & 0.68 & 0.60 & 0.28 & 0.14 & 0.34 & 0.17 & 0.15 & 0.39 \\
\hline $\mathrm{CaO}$ & 2.50 & 2.77 & 2.64 & 2.40 & 2.01 & 2.46 & 1.32 & 1.44 & 0.69 & 1.53 & 0.70 & 0.68 & 0.42 & 0.33 & 0.89 \\
\hline $\mathrm{Na}_{2} \mathrm{O}$ & 4.03 & 4.38 & 4.49 & 3.87 & 4.36 & 4.23 & 4.25 & 4.18 & 4.25 & 4.00 & 4.78 & 4.26 & 4.42 & 4.52 & 4.33 \\
\hline $\mathrm{K}_{2} \mathrm{O}$ & 2.26 & 1.95 & 2.05 & 2.12 & 1.76 & 2.03 & 3.50 & 3.50 & 3.65 & 3.98 & 4.22 & 4.14 & 4.42 & 4.10 & 3.94 \\
\hline $\mathrm{TiO}_{2}$ & 0.32 & 0.24 & 0.24 & 0.24 & 0.22 & 0.25 & 0.19 & 0.15 & 0.10 & 0.07 & 0.01 & 0.10 & 0.01 & 0.14 & 0.10 \\
\hline $\mathrm{P}_{2} \mathrm{O}_{5}$ & 0.19 & 0.09 & 0.12 & 0.15 & 0.13 & 0.14 & 0.11 & 0.10 & 0.05 & 0.05 & 0.02 & 0.03 & 0.01 & 0.02 & 0.05 \\
\hline LOI & 0.77 & 0.95 & 0.80 & 1.25 & 0.60 & 0.87 & 0.75 & 1.10 & 1.40 & 0.70 & 0.65 & 0.65 & 0.45 & 0.34 & 0.76 \\
\hline $\mathrm{Qz}$ & 29.63 & 28.16 & 28.17 & 33.72 & 34.71 & 30.88 & 29.24 & 29.55 & 30.81 & 30.70 & 27.66 & 30.81 & 30.00 & 31.81 & 30.07 \\
\hline $\mathrm{An}$ & 11.16 & 13.15 & 12.31 & 10.93 & 9.12 & 11.34 & 5.83 & 6.49 & 3.10 & 7.26 & 3.34 & 3.18 & 2.02 & 1.51 & 4.09 \\
\hline $\mathrm{Ab}$ & 34.10 & 37.06 & 37.99 & 32.75 & 36.89 & 35.76 & 35.96 & 35.37 & 35.96 & 33.85 & 40.45 & 36.05 & 37.40 & 38.25 & 36.66 \\
\hline Or & 13.36 & 11.52 & 12.11 & 12.53 & 10.40 & 11.98 & 20.68 & 20.68 & 21.57 & 23.52 & 24.94 & 24.47 & 26.12 & 24.23 & 23.28 \\
\hline $\mathrm{C}$ & 2.60 & 2.33 & 2.63 & 2.08 & 2.81 & 2.49 & 2.04 & 1.79 & 2.91 & 1.29 & 1.44 & 2.01 & 2.75 & 1.98 & 2.03 \\
\hline Нyp & 4.42 & 3.94 & 3.45 & 3.55 & 3.05 & 3.68 & 2.91 & 2.63 & 2.32 & 1.38 & 0.76 & 1.42 & 0.71 & 0.75 & 1.61 \\
\hline Il & 0.61 & 0.46 & 0.46 & 0.46 & 0.42 & 0.48 & 0.36 & 0.28 & 0.19 & 0.13 & 0.02 & 0.19 & 0.02 & 0.27 & 0.18 \\
\hline $\mathrm{Mt}$ & 2.48 & 1.75 & 1.59 & 2.09 & 1.44 & 1.87 & 1.73 & 1.54 & 1.29 & 0.83 & 0.57 & 0.96 & 0.38 & 0.80 & 1.01 \\
\hline $\mathrm{Ap}$ & 0.44 & 0.21 & 0.28 & 0.35 & 0.30 & 0.32 & 0.25 & 0.23 & 0.12 & 0.12 & 0.05 & 0.07 & 0.02 & 0.05 & 0.11 \\
\hline Agp. I & 0.58 & 0.57 & 0.57 & 0.59 & 0.60 & 0.58 & 0.72 & 0.72 & 0.73 & 0.73 & 0.82 & 0.78 & 0.78 & 0.82 & 0.76 \\
\hline ASI & 1.18 & 1.16 & 1.17 & 1.15 & 1.21 & 1.17 & 1.15 & 1.13 & 1.24 & 1.09 & 1.10 & 1.16 & 1.21 & 1.16 & 1.15 \\
\hline MALI & 3.79 & 3.56 & 3.90 & 3.59 & 4.11 & 3.79 & 6.43 & 6.24 & 7.21 & 6.45 & 8.30 & 7.72 & 8.42 & 8.29 & 7.25 \\
\hline DI & 77.09 & 76.74 & 78.27 & 79.00 & 82.00 & 78.62 & 85.88 & 85.60 & 88.34 & 88.07 & 93.05 & 91.33 & 93.52 & 94.29 & 90.01 \\
\hline
\end{tabular}

Table 1, Continued

\begin{tabular}{|c|c|c|c|c|c|c|c|c|c|c|c|c|c|c|c|}
\hline & \multicolumn{6}{|c|}{ Less fractionated granite } & \multicolumn{9}{|c|}{ Highly fractionated granite } \\
\hline & 1 & 2 & 3 & 4 & 5 & Average & 6 & 7 & 8 & 9 & 10 & 11 & 12 & 13 & Average \\
\hline $\mathrm{Ba}$ & 681 & 477 & 298 & 1275 & 462 & 638.60 & 686 & 687 & 553 & 764 & 99 & 631 & 57 & 138 & 451.88 \\
\hline $\mathrm{Sr}$ & 374 & 442 & 413 & 337 & 496 & 412.40 & 193 & 161 & 121 & 190 & 15 & 99 & 12 & 23 & 101.75 \\
\hline $\mathrm{Rb}$ & 70 & 58 & 55 & 42 & 56 & 56.20 & 14 & 90 & 72 & 132 & 158 & 90 & 166 & 121 & 105.38 \\
\hline $\mathrm{Cu}$ & 33 & 44 & 19 & 32 & 44 & 34.40 & 37 & 23 & 29 & 9 & 31 & 9 & 8 & 6 & 19.00 \\
\hline $\mathrm{Co}$ & 66 & 58 & 53 & 10 & 35 & 44.40 & 29 & 20 & 25 & 27 & 10 & 31 & 21 & 11 & 21.75 \\
\hline $\mathrm{Ni}$ & 32 & 36 & 11 & 53 & 8 & 28.00 & 8 & 18 & 45 & 28 & 42 & 26 & 49 & 37 & 31.63 \\
\hline $\mathrm{Cr}$ & 29 & & 18 & 13 & 13 & 18.25 & 19 & 15 & & & 7 & 15 & 12 & & 13.60 \\
\hline $\mathrm{Zn}$ & 69 & 65 & 48 & 65 & 60 & 61.40 & 66 & 54 & 51 & 31 & 61 & 93 & 78 & 74 & 63.50 \\
\hline $\mathrm{Pb}$ & 10 & 6 & 6 & & 2 & 6.00 & 25 & 17 & 31 & 22 & 6 & 32 & 17 & 1 & 18.88 \\
\hline $\mathrm{V}$ & 66 & 49 & 27 & 38 & 35 & 43.00 & 29 & 21 & 17 & & 4 & 5 & & & 15.20 \\
\hline $\mathrm{Ga}$ & 13 & 30 & 30 & 17 & 22 & 22.40 & 20 & 143 & 21 & 19 & 29 & 22 & 36 & 23 & 39.13 \\
\hline $\mathrm{Y}$ & 48 & 14 & 11 & 20 & & 23.25 & 66 & 39 & 31 & 48 & 130 & 81 & 89 & 48 & 66.50 \\
\hline $\mathrm{Nb}$ & 4 & 4 & 2 & 7 & 2 & 3.80 & 6 & 8 & 10 & 6 & 10 & 8 & 8 & 8 & 8.00 \\
\hline $\mathrm{Zr}$ & 224 & 138 & 151 & 74 & 158 & 149.00 & 179 & 143 & 123 & 92 & 93 & 138 & 112 & 74 & 119.25 \\
\hline $\mathrm{U}$ & 5 & 3 & 5 & 1 & & 3.50 & & & 3 & 5 & 1 & 2 & 9 & 3 & 3.83 \\
\hline $\mathrm{Th}$ & 7 & 2 & 4 & 3 & & 4.00 & 8 & & 8 & 9 & 2 & 8 & 14 & & 8.17 \\
\hline $\mathrm{La}$ & 34 & 39 & 8 & 58 & & 34.75 & & 32 & 14 & 15 & 19 & 27 & & 32 & 23.17 \\
\hline $\mathrm{Ce}$ & 80 & 70 & 194 & 47 & 87 & 95.60 & 199 & 44 & 107 & 304 & 19 & 164 & & 15 & 121.71 \\
\hline
\end{tabular}

The studied samples are classified as sub-alkaline granite, according to (Rickwood, 1989) and Le Maitre et al., (1989) respectively, Fig. 3. The HFG are high-K according to (Le Maitre et al., 1989), while the LFG are medium K-series, Fig. 4.

The agpaitic index (Agp. I), reveals a calc-alkaline nature for both LFG and HFG, as the average agpaitic indices are 0.58 and 0.76 for LFG and HFG respectively, the latter exhibits a slight tendency towards the alkaline field (Fig. 5). The averages of alumina saturation index (ASI), (Shand, 1947; Zen, 1988), for LFG and HFG are 1.17 and 1.15 respectively, i.e., peraluminous, (ASI $>1$ ), however, the ASI remains nearly constant with increasing the fractionation index Fig. 6.

The values of the modified alkali-lime index (MALI) depend on the fractionation trends of the mineral phases that have crystallized and removed from their parental melts, (Frost et al., 2001). Figure 7A illustrates the relation between (MALI) and the silica contents in various mineral phases (data after Frost and Frost, 2008), where BGR plot in the alkali-calcic and calcic-alkali fields, and are characterized by relatively high 
Discrimination of less and high fractionated granitic rocks

MALI values. The common mineral phases that contributed, essentially, to produce such high MALI values are K-feldspars and plagioclase. The plagioclase composition varies from $A b_{70}$ at $L F G$ phase to $A b_{85}$ at the end of HFG phase (Fig. 7B).

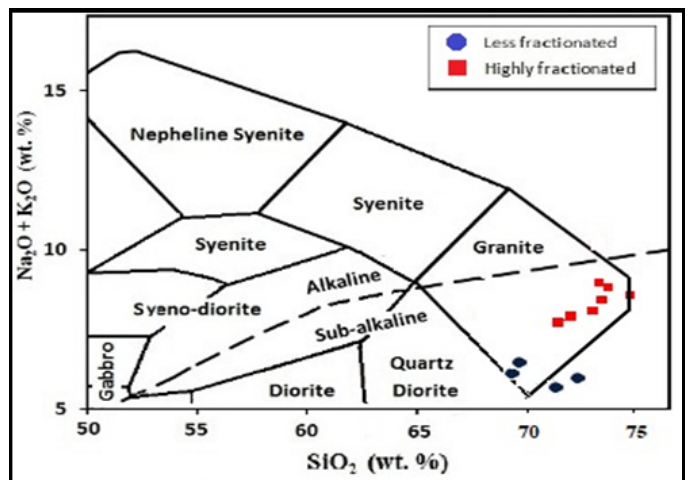

Fig. 3: Total alkali- silica diagram for the studied granites, the heavy dashed line, of (Rickwood, 1989), separates between sub-alkaline and alkaline fields, the solid lines represent the chemical classification fields, (Le Maitre et al., 1989), The BGR plot mainly in the sub alkaline granite fields.

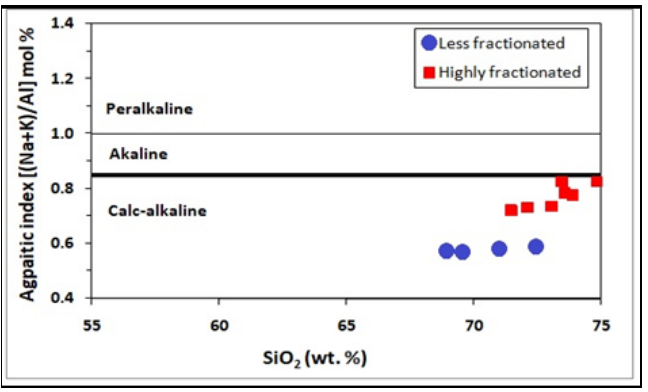

Fig. 5: $\mathrm{SiO}_{2}$ versus agpaitic index $(\mathrm{AI}=\mathrm{Na}+\mathrm{K} / \mathrm{Al} \mathrm{mol} \%)$ showing an overall calc-alkaline affinity, all LFG and most of HFG samples have agpaitic index $>0.85$ and plot within calc-alkaline field, except for two HFG samples of agpaitic index, plot in the alkaline and peralkaline fields.

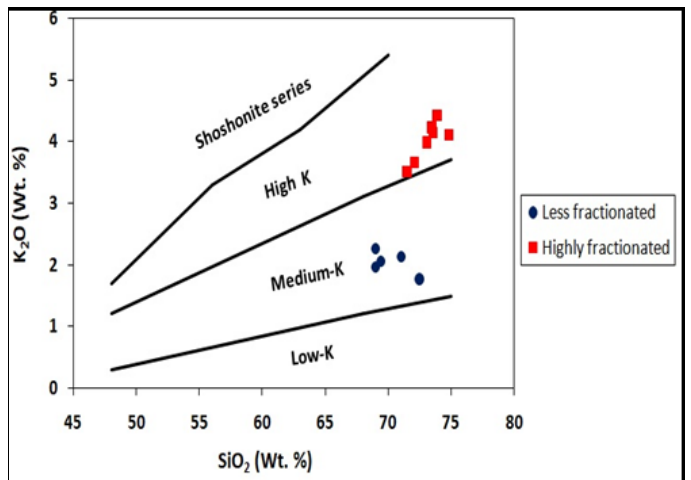

Fig. 4: $\mathrm{SiO}_{2}$ versus $\mathrm{K}_{2} \mathrm{O}$, fields after (Le Maitre et al., 1989), the LFG samples plot in the medium-K series field, while HFG samples plot in the high K-field and fractionate toward shoshonite series.

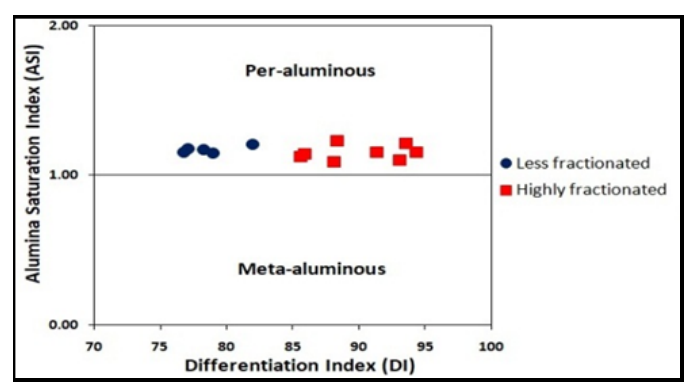

Fig. 6: Differentiation index of Thronton and Tuttle, (1960), versus alumina saturation index, all samples plot in the both sides close to the separating line of (Zen, 1988), between per-aluminous and metaaluminous, with relative deviation toward the metaaluminous field,

Fig. 7: $\mathrm{SiO}_{2}$ versus (MALI), the three solid curved lines separate fields c: calcic; c-a: calcic alkali; a-c: alkali calcic and a: alkalic, (Frost et al. 2001). (A): The BGR are characterized by relative high MALI values, most of LFG plot between calcic alkali and alkali calcic lines, while HFG plot between alkali calcic and alkali lines. (B): The BGR are related to plagioclase composition ranges from $\mathrm{An} 15$ to $\mathrm{An}_{20}$ for $\mathrm{HFG}$ and from $\mathrm{An}_{25}$ to $\mathrm{An}_{30}$ for LFG.
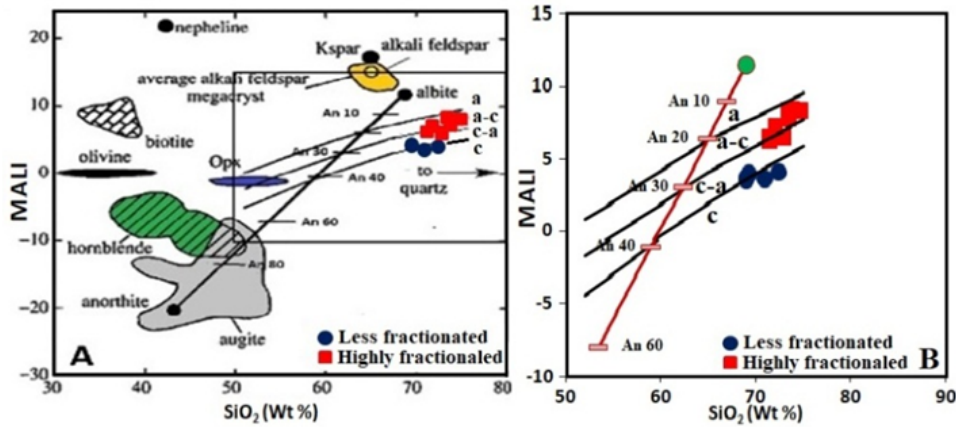

The studied BGR show a narrow range of geochemical variations, but such variations are far from random, especially, when using $\mathrm{SiO}_{2}$ as fractionation index (Fig. 8). $\mathrm{FeO}^{\mathrm{t}}, \mathrm{Al}_{2} \mathrm{O}_{3}, \mathrm{CaO}$, and $\mathrm{MgO}$ correlate negatively with the increasing silica contents, such negative correlation may be related to the fractionation of biotite. The total alkalis correlate positively towards the more fractionated varieties.

The immobile trace elements $(\mathrm{Nb}, \mathrm{Y} \& \mathrm{Ce})$ correlate positively with increasing $\mathrm{SiO}_{2}$ contents, while $\mathrm{Zr}$ correlates negatively, indicating a dominant role of fractional crystallization. The compatible transition 
elements such as $\mathrm{Cr}$, Co and $\mathrm{V}$, correlate negatively with increasing silica contents, while $\mathrm{Pb}$ and $\mathrm{Zn}$ don't exhibit remarked trends. Barium correlates positively with increasing $\mathrm{SiO}_{2}$ content while $\mathrm{Sr}$ and $\mathrm{Rb}$ correlate negatively (Fig. 8). Th, Ga and La don't attain coherent trends between LFG and the more evolved HFG with increasing of $\mathrm{SiO}_{2}$ (Fig. 8).

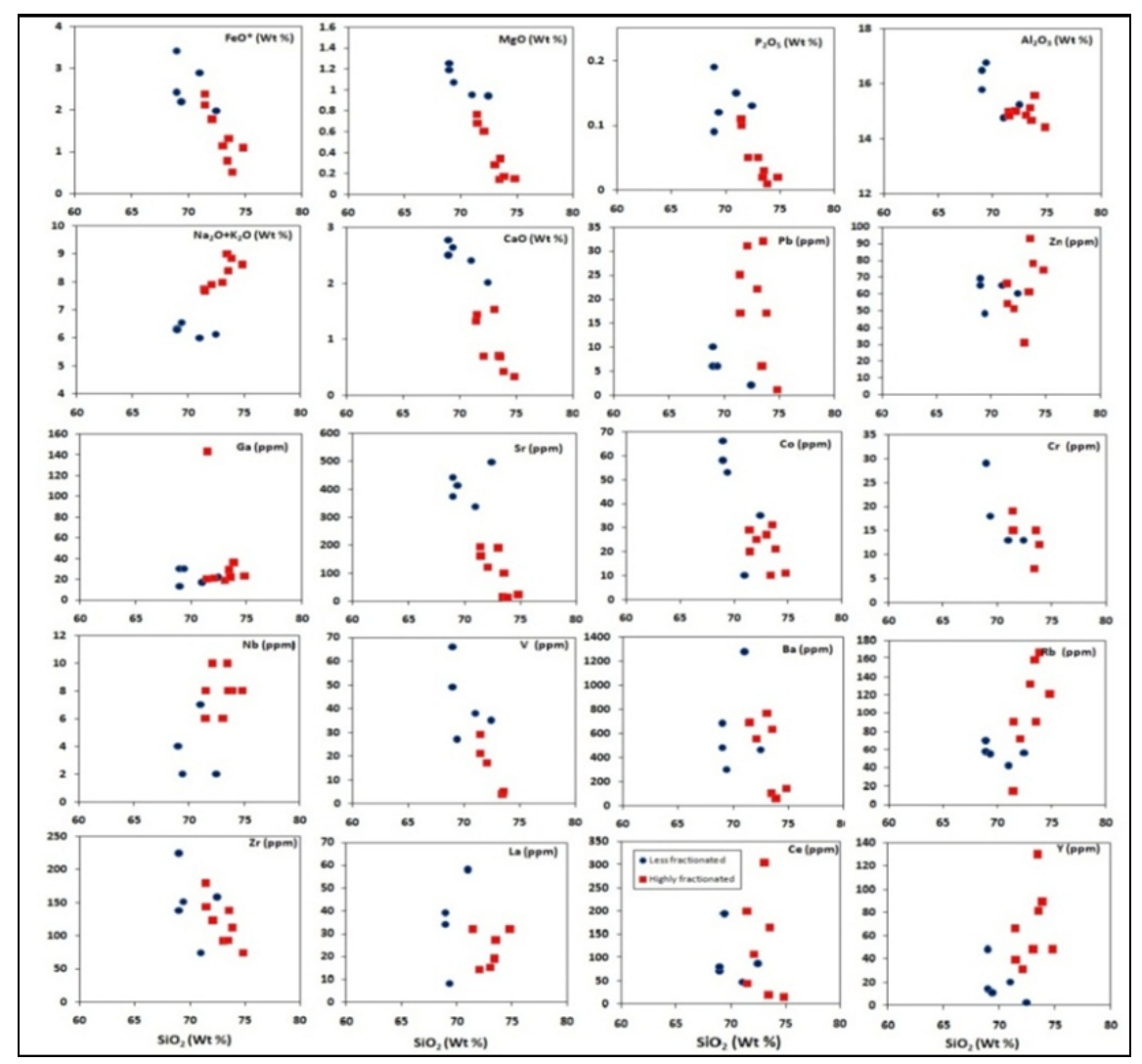

Fig. 8: $\mathrm{SiO}_{2}$ versus major and trace elements

The interelements variation diagrams reveals a proper role of fractional crystallization processes, resulting in the production of the HFG from the more basic and less fractionated granite. Figure 9A shows a good linear trend between $\mathrm{Sr}$ and $\mathrm{CaO}$ from the $\mathrm{LFG}$ to the HFG. However, the relation between $\mathrm{Sr}$ and $\mathrm{Ba}$ reveals a role of crustal contamination during the evolution of the HFG (Fig. 9 B).

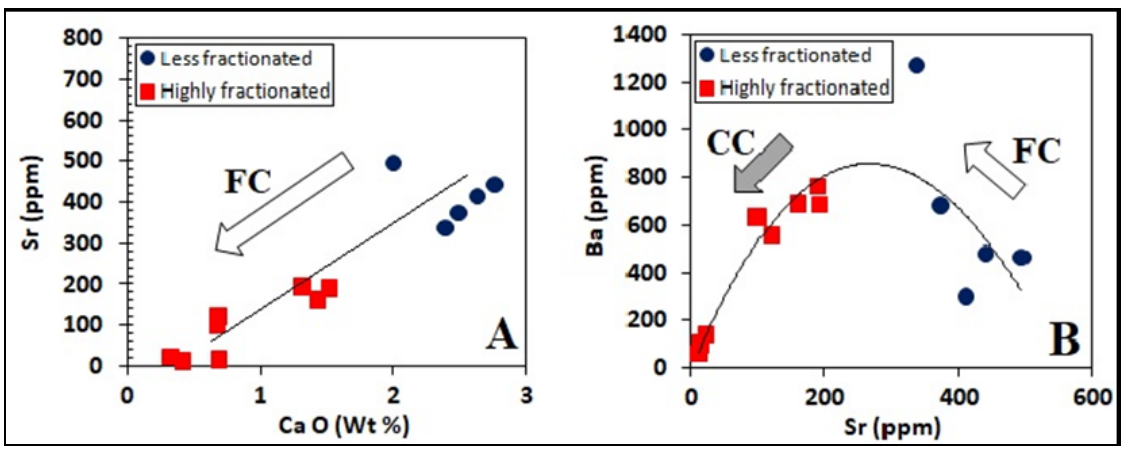

Fig. 9: A: linear relation between $\mathrm{CaO}$ and Sr reflecting a main role of fractional crystallization (FC). (B): Relation between $\mathrm{Sr}$ and $\mathrm{Ba}$ exhibiting a combined fractionation processes between fractional crystallization (FC) and crustal contamination (CC).

Figure 10 shows the relation between $\mathrm{FeO}^{*} /(\mathrm{FeO} *+\mathrm{MgO})$ versus $\mathrm{SiO}_{2}$. The solid line differentiates between ferroan and magnesian plutons, the figure also differentiate between A-type granite and cordilleran granite, (data and fields from Frost et al., 2001). From this diagram, it is clear that the present BGR plot in the magnesian field - cordilleran granites. 
Discrimination of less and high fractionated granitic rocks

The compatible transition elements are concentrated in the mafic solid phases and become impoverished in residual melts (All'egre et al., 1968). In the Ti - Zn spider diagram (Fig. 11), the elements are normalized to primitive mantle (values from Sun, 1982), it is clear that the resultant patterns attain characteristic troughs at $\mathrm{Cr}$ and $\mathrm{Ni}$, these troughs becomes deeper with the increasing differentiation from LFG to HFG.

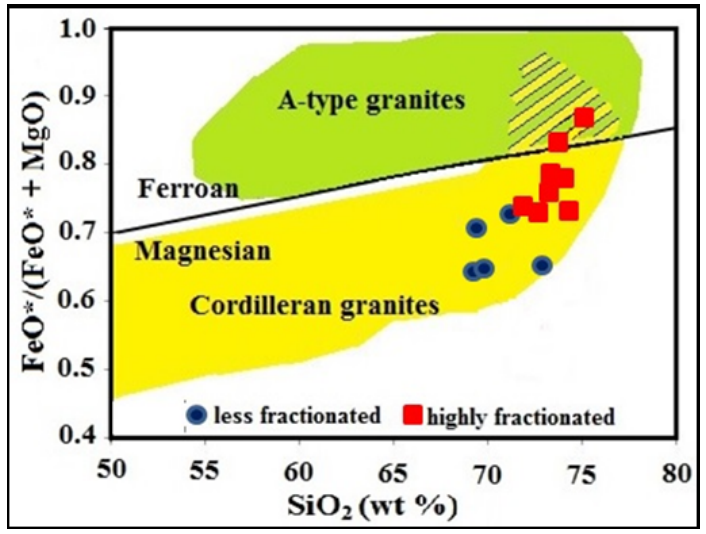

Fig. 10: $\mathrm{SiO}_{2}$ versus $\mathrm{FeO}^{*} /\left(\mathrm{FeO}^{*}+\mathrm{MgO}\right)$ diagram, data and fields are from (Frost et al., 2001).

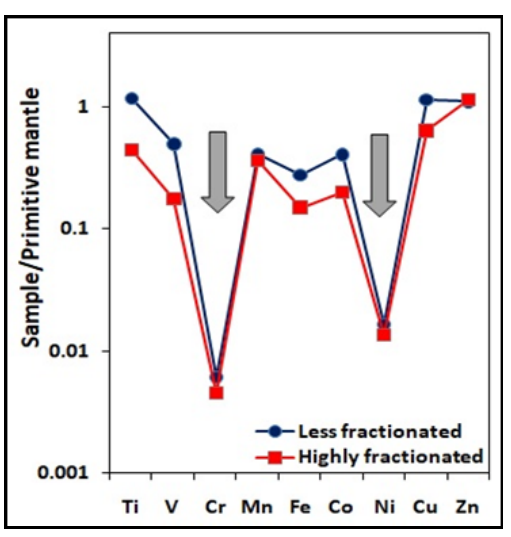

Fig. 11: Primitive mantle normalized transition elements for BGR, arrows are pointing out to the direction of fractionation, normalization values are after (Sun, 1982).

The BGR normalized to chondritic values of Thompson (1982) were correlated with orogenic granites (Itype granites, M-type granites, S-type granites) and anorogenic granites (A-type granites), (data from Whalen et al., 1987; Fig. 12). From this diagram it is clear that the resulted LFG and HFG patterns are enriched in mobile elements $(\mathrm{Ba}, \mathrm{Rb}$ and $\mathrm{K})$ and depleted in immobile $\mathrm{Nb}, \mathrm{Zr}$ and $\mathrm{Ti}$, more akining to the ororgenic granites. To the left hand side of the diagram, the LFG and HFG patterns are more akin to I-type granite reflecting the role of the subducted oceanic slab, while to the right side of the diagram, the present two patterns are more close to the M-type granite reflecting the role of the overlying thick mantle wedge.

The role of the mantle wedge is also noticed when applying $\mathrm{Y}+\mathrm{Nb}$ versus $\mathrm{Rb}$ diagram of Pearce et al. (1984; Fig. 13), where most of LFG samples are classified as VAG, while the HFG plot in both VAG and WPG, being due to the high contents of $\mathrm{Nb}$ and $\mathrm{Y}$, and this reflects a role of thick and fertile mantle wedge as a source of enrichment during the formation of BGR parent melt.

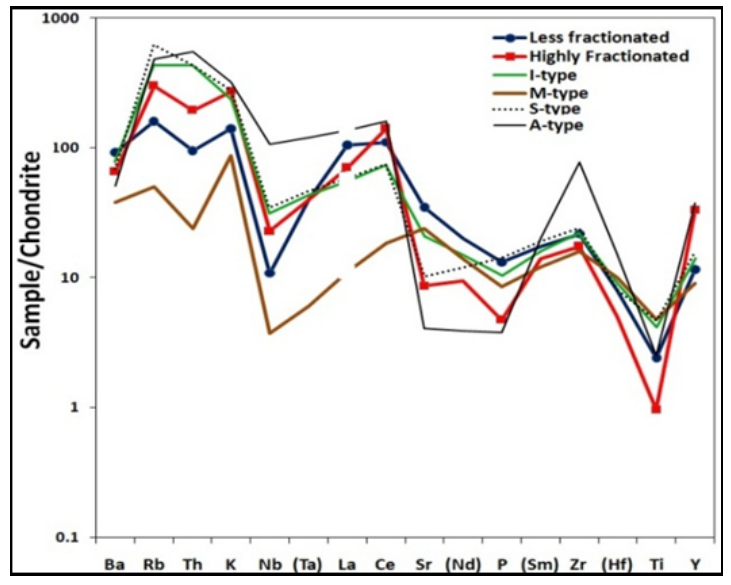

Fig. 12: Chondrite normalized incompatible elements for BGR, normalization values are after Thompson, (1982), correlated with I-type granites, M-type granites, S-type granites and A-type granites, (data from Whalen et al., 1987).

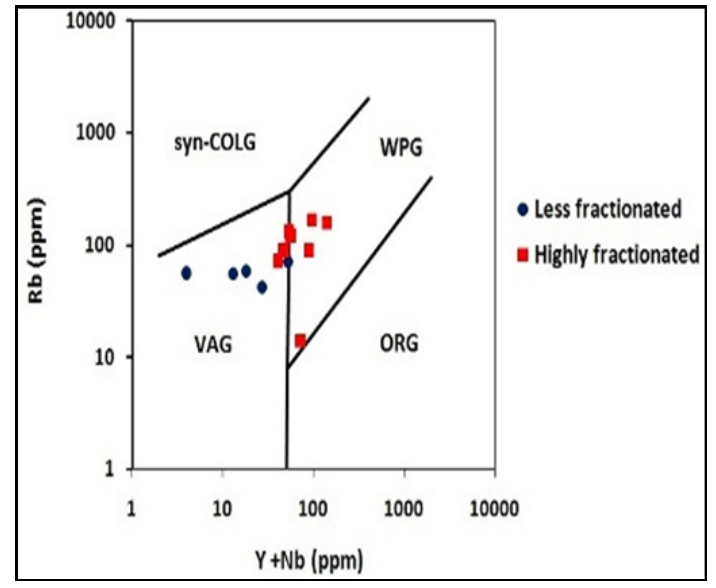

Fig. 13: $\mathrm{Y}+\mathrm{Nb}$ versus $\mathrm{Rb}$ variation diagram; fields are after (Pearce et al., 1984). 


\section{Classification of granitic rocks according to weathering processes}

The chemical index of alteration (CIA) was proposed by Nesbitt and Young (1982) to discriminate the progress of alteration of K-feldspars and plagioclase to clay minerals. The CIA values for unweathered igneous rocks equal or less than 50, while if the CIA values exceed 50 this means that the feldspars are altered to aluminous clays like gibbsite and kaolinite as a result of chemical weathering, Fedo et al., (1995). Fig. 14, illustrates the relation between the CIA (CIA $\left.=\mathrm{Al}_{2} \mathrm{O}_{3} * 100 / \mathrm{Al}_{2} \mathrm{O}_{3}+\mathrm{K}_{2} \mathrm{O}+\mathrm{Na}_{2} \mathrm{O}+\mathrm{CaO}\right)$ and $\mathrm{Al}_{2} \mathrm{O}_{3} / \mathrm{Na}_{2} \mathrm{O}$, (all are in cation proportions) Servaraj and Arthur, (2006), the weathering increases as the CIA values increase from right to left, it is clear that the present BGR plot in the low weathering field (CIA = 5060 ), with slight tendencies for the LFG (average CIA $=53.7$ ) to be more weathered than the HFG (average $\mathrm{CIA}=53.2)$.

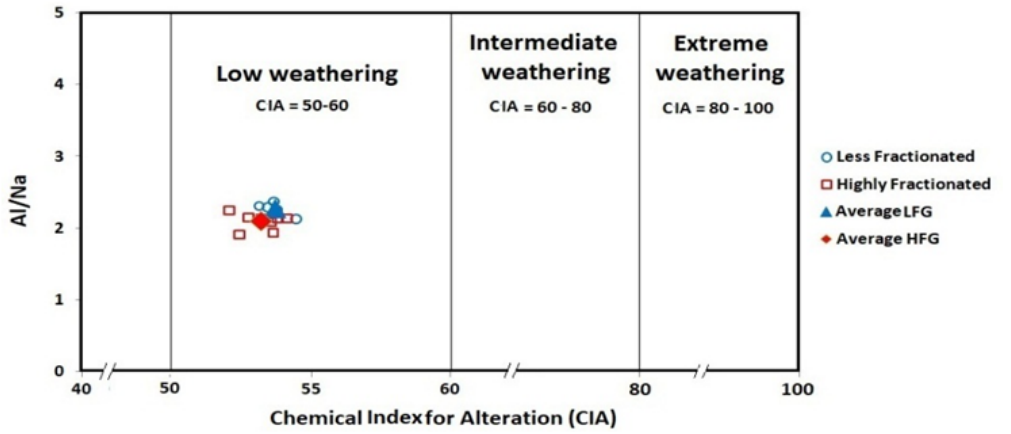

Fig. 14: A1/Na versus CIA plot for Biririg granitic rocks. (After Servaraj and Arthur, 2006)

The A-CN-K ternary diagram, Nesbitt and Young, (1984), where $\left(\mathrm{CN}=\mathrm{CaO}+\mathrm{Na}_{2} \mathrm{O}, \mathrm{K}=\mathrm{K}_{2} \mathrm{O}, \mathrm{A}=\mathrm{Al}_{2} \mathrm{O}_{3}\right.$, all are in molecular proportions) is successfully used to evaluate the composition of fresh rocks and to determine their weathering trends. The chemical index of alteration (CIA) values of the unweathered igneous rocks plot close to feldspar line i.e. close to 50, Fedo et al., (1995). As weathering proceeds, the kaolinitization of feldspar minerals and chloritization of amphiboles and biotite crystals proceeds, resulting in leaching of $\mathrm{CaO}, \mathrm{Na}_{2} \mathrm{O}$ and $\mathrm{K}_{2} \mathrm{O}$ and the rock becomes more enriched in $\mathrm{Al}_{2} \mathrm{O}_{3}$, i.e. the extremely weathered samples plot towards "A" apex. On the A-CN-K ternary diagram, Fig. 15, it is clear that, the two types of granite, plot on or close to the plagioclase line, in the low weathering field. The plotting obtained in Fig. 15, is confirmed by A-CNK-FM ternary digram as illustrated in Fig. 16, where the granitic rocks are low weathered as they plot, clustered and slightly above the feldspar- biotite line.

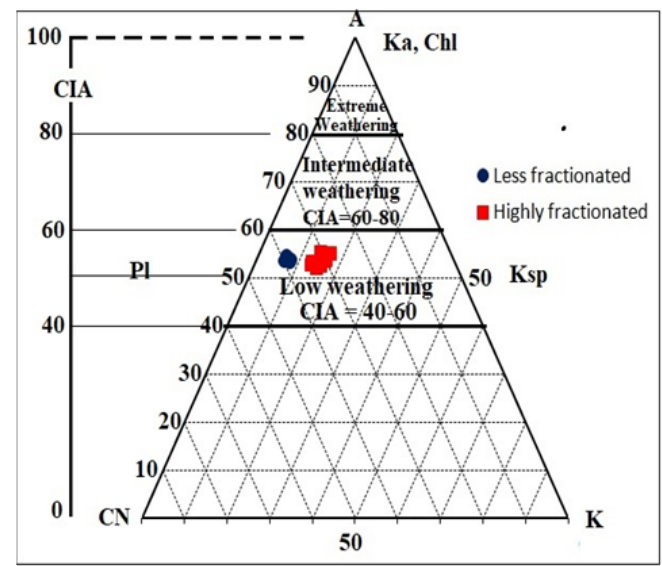

Fig. 15: A-CN-K ternary diagram, Nesbitt and Young, (1984), $\mathrm{CIA}=\left(\mathrm{Al}_{2} \mathrm{O}_{3} / \mathrm{Al}_{2} \mathrm{O}_{3}+\mathrm{CaO}+\mathrm{Na}_{2} \mathrm{O}+\mathrm{K}_{2} \mathrm{O}\right) \times 100 . \mathrm{Pl}=$ Plagioclase, $\mathrm{K}-\mathrm{fs}=$ Potash feldspar, $\mathrm{Ka}=$ Kaoline and $\mathrm{Chl}=$ Chlorite. Both granitic types plot in the low weathering field on the feldspar line. However the average of the less fractionated pinkish white granite is relatively more enriched with $\mathrm{Al}_{2} \mathrm{O}_{3}$.

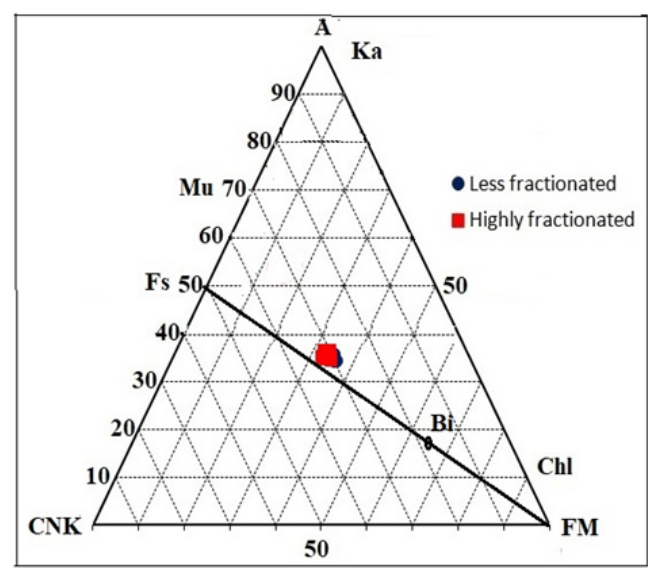

Fig. 16: CNK - FM - A, ternary diagram, Nesbitt and Young, (1989), $\mathrm{CNK}=\mathrm{CaO}+\mathrm{Na}_{2} \mathrm{O}+\mathrm{K}_{2} \mathrm{O}$, $\mathrm{FM}=\mathrm{FeO}$ (total iron as ferrous) $+\mathrm{MgO}, \mathrm{A}=\mathrm{Al}_{2} \mathrm{O}_{3}$, (in molecular proportion). Fs: feldspars, $\mathrm{Mu}$ : muscovite, Ka: Kaolin, Chl: Chlorite, Bi: Biotite. 
Discrimination of less and high fractionated granitic rocks

The qualitative and quantitative weathering classification scheme is described in the description, for example the colour change (Lee, 1987), chemical weathering of feldspars or biotites (Onodera et al., 1974; Irfan and Dearman, 1978b; Cole and Sandy, 1980; Hencher and Martin, 1982; Irfan and Powell, 1985; Raj, 1985; Lee, 1987). There is a series of 6 types of weathering grade (Table 2) depending upon the tint and discoloration; texture and fabric; breakdown (Gupta, 1997).

According to the classification of IAEG, (1981) and ISRM, (1981), the granitic rocks under investigation are classified into WI and WII grade of weathering. The less fractionated pinkish white granite in the area of study is classified to WII and the highly fractionated pink granite is classified as WI according to the grade of weathering, Table 2. As the weathering increases, the solubility rate increases. In weathered samples, colour of the rock changes is especially along microfractures. Changes in microfabric of the rocks under study are due to weathering.

The rock samples in WI weathering grade, no significant staining and the minerals tightly bonded as well as a few of feldspars are gritty and hair line cracks are visible in small quantity. In WII weathering grade, the rocks under study are slightly stained and few minerals are gritty in appearance and few feldspars (plagioclase) are decomposed, (Table 3).

Table 2: Weathering classification of granitic rocks (IAEG, 1981 and ISRM, 1981).

\begin{tabular}{|c|c|}
\hline Visual identification description & Grades \\
\hline No discoloration. Grains have a vitreous luster. Virtually no major cracks are present. & Fresh rock (W0) \\
\hline $\begin{array}{l}\text { No significant staining. Luster of minerals. Grains are tightly bonded. Few of feldspars are } \\
\text { gritty. Hairline cracks are visible in small quantity. }\end{array}$ & Slightly weathered (WI) \\
\hline $\begin{array}{l}\text { Slightly stained. Few grains are gritty in appearance. Altered microcracks are visible, but } \\
\text { they are tight. } \\
\text { Few of feldspars (plagioclase) are decomposed. Feldspar can be scratched. Sample can be } \\
\text { broken by one firm blow of a geological hammer. }\end{array}$ & Moderately weathered (WII) \\
\hline $\begin{array}{l}\text { Discolored and highly stained into a pale brown color. Most grains are gritty and clayey. } \\
\text { Loosely bonded fractured grains of quartz. Microcrack is filled with clays. Few of feldspars } \\
\text { are not decomposed. }\end{array}$ & Highly weathered (WIII) \\
\hline $\begin{array}{l}\text { Completely discolored. Specks of white clays are present. Very loosely bonded grains. } \\
\text { Micro fractures are open and filled with clay and air. Sample can be crumbled by fingers. }\end{array}$ & Completely weathered (WIV) \\
\hline Original texture is lost. The samples become granular with virtually no strength. & Residual soil (WV) \\
\hline
\end{tabular}

Table 3, Weathering classification of the rock mass.

\begin{tabular}{|c|c|c|c|}
\hline & Hosting minerals & $\begin{array}{l}\text { Less fractionated pinkish white } \\
\text { granite (WII) }\end{array}$ & $\begin{array}{l}\text { Highly fractionated pink } \\
\text { Granite (WI) }\end{array}$ \\
\hline \multicolumn{4}{|c|}{ Secondary minerals: } \\
\hline Kaoline & Feldspars & +++++ & +++ \\
\hline Sericite & Feldspars & $\begin{array}{c}++ \\
\end{array}$ & + \\
\hline Epidote & Feldspars & +++ & + \\
\hline Calcite & Feldspars & ++++ & + \\
\hline Chlorite & Biotite - Amphiboles & ++++ & + \\
\hline Chloritoid & Biotite & $\begin{array}{l}++ \\
\end{array}$ & + \\
\hline \multicolumn{4}{|c|}{ Accessory minerals: } \\
\hline Sphene & & + & + \\
\hline Apatite & & + & + \\
\hline Iron oxides & & ++++ & +++ \\
\hline
\end{tabular}

\section{CONCLUSION}

The Biririg granitic rocks are of leucocratic nature evolved from calc-alkaline magma, the early stage of the less fractionated granites (LFG) is medium-K, having averages modified alkali lime index (3.79), agpatic index (0.58) alumina saturation index (1.17) and average differentiation index (78.62). After the evolution of the less fractionated granite, and prior to the eruption of the highly fractionated granites, the residual melts become more alkaline, as the averages modified alkali lime index (7.25), agpaitic index (0.76), alumina saturation index (1.15) and average differentiation index (90.01). 
The rocks under investigation were classified into WI and WII according to the grade of weathering, where the mineralogical, chemical and engineering properties changed. The pinkish white granite in the area of study is classified to WII, while the pink granite is classified as WI. Most elements redistribute in their newly formed secondary minerals. The differences observed in the composition of the WII samples relative to the slightly weathered WI ones could be attributed to the fractional crystallization of melt, original magmatic features and/or crustal contamination.

The inter elements variation diagrams revealed a main role of fractional crystallization governing the fractionation processes resulting in production of the highly fractionated granites from the more basic, less fractionated granites, however a minor role of crustal contamination is also encountered in the latest phases of fractionation. The present granite exhibited geochemical characteristics more akin to orogenic granites, mostly evolved at active continental margins, as there are three main sources of enrichment namely; subduction zone, thick mantle wedge and sub-continental lithospheric mantle.

\section{REFERENCES}

Akaad, M. K. and El Ramly, M. F., (1960): Geological history and classification of the basement rocks of the Central Eastern Desert of Egypt. Geol. Surv. Egypt, Paper no.9: 24p.

All'egre, C. J., Javoy, M. and Michard, G., (1968): Etude de la distribution et de l'abundance des elements de transition dans l'ecorce terrestre compare a celles des terrs rares. In L. H. Ahrens (ed.). Origin and Distribution of the Elements. Pergamon, Oxford. P913.

Dearman, W. R., (1995): Description and classification of weathered rocks for engineering purposes: the background to the BS5930:1981 proposals. Quart. J. Engineering Geol. \& Hydrogeol.; 28 (3): 267-276.

Arıkan, F., Ulusay, R. and Aydın, N., (2007): Characterization of weathered acidic volcanic rocks and a weathering classification based on a rating System. Bull. Engineer. Geol. \& the Environ. 66: 415-430.

Ceryan, S., Zorlu, K., Gökçeoğlu, C. and Temel, A., (2008): The use of cation packing index for characterizing the weathering degree of granitic rocks. Engineer. Geol., 98, 60-74.

Cole, W. F. and Sandy, M. J., (1980): A proposed secondary mineral rating for basalt road aggregate durability. Australian Road Res., 10(3), 27-3.

El-Gaby S., (1975): Petrochemistry and Geochemistry of some granites from Egypt. N. Jb. Miner. Alt. (124), 147-199.

El-Gaby, S., List, K. F. and Tehrani, R., (1988): Geology, evolution and metallogenesis of the Pan-Africanm belt in Egypt. Andreas Vogel, Berlin.

El Ramly, M. F., (1972): A new geological map for the basement rocks in the Eastern Desert and Southern Western Desert of Egypt, Scale 1:1.000.000. Annal. Geol. Surv. Egypt. 2, 1-18.

El-Ramly, M. F., Greiling, R. O., Rashwan, A. A., Rasmy, A. H., (1993): Geologic map of Wadi Hafafit area. Scale 1:100.000. Egypt. Geol. Surv. 68.

El-Shazly, E. M., (1964): On the classificationof the Precambrian and other rocks of magmatic affiliation in Egypt. U. A. R. Geol. Congress, India. Sect. 10.

Fedo, C. M., Nesbitt, H. W. and Young, G. M., (1995): Unraveling the effects of potassium metasomatism in sedimentary rocks and paleosols, with implications for paleoweathering conditions and provenance. Geology, 23(10), 921-924.

Frost, B. R. and Frost, C. D., (2008): A Geochemical Classification for Feldspathic Igneous Rocks.

Frost, B. R., Arculus, R. J., Barnes, C. G., Collins, W. J., Ellis, D. J. and Frost, C. D., (2001): A geochemical classification of granitic rocks. J. Petrol., 42, 2033-2048.

Gokceoglu, C. and Aksoy, H., (2000): New approaches to the characterization of clay-bearing, densily jointed and weak rock masses. Engineer. Geol., 58, 1-38.

Gokceoglu, C., Zorlu, K., Ceryan, S. and Nefeslioglu, H. A. A. (2009): Comparative study on indirect determination of degree of weathering of granites from some physical and strength parameters by two soft computing techniques. Materials Characterization. 60, 1317-1327.

Guolin, R. and Yushan, L., (1990): Engineering geological zonation of Xiamen granitic weathered crust and bearing capacity of residual soil. $6^{\text {th }}$ International IAEG Congress, 1989-1996, Balkema Rotterdam. 
Discrimination of less and high fractionated granitic rocks

Gupta, A. S., (1997): Engineering behaviour and classification of weathered rocks. Ph. D. thesis submitted to Indian Institute of Technology, Delhi.

Gupta, A. S. and Rao, K. S., (2001): Weathering indices and their applicability for crystalline rocks. Bulletin of Engineering Geology and the Environment. 60, 201- 221.

Hashad, A. H., (1980): Present status of geochemical data of the Egyptian Basement Complex. Symp. Evolution and Mineralization of the Arabian-Nubian Shield, King Abdulaziz Univ., Jeddah. 3, 31-46.

Hassan, M.A. and Hashad, A. H,. (1990): Precambrian of Egypt. In: Said, R., Ed., The Geology of Egypt, Rotterdam, Balkama, 201-245.

Hencher, S. R. and Martin, R. P., (1982): The description and classification of weathered rocks in Hong Kong for engineering purposes. In Proc. $7^{\text {th }}$ Southeast Asian geotech. conf. 125-142.

Heiri, O., Lotter, A. and Lemcke, G., (2001): Loss on ignition as a method for estimating organic and carbonate content. J. Paleolimnol. 25(1), 101-110.

Hussein, A.A., Ali, M.M. and El-Ramly, M.F., (1982): A Proposed New Classification of the Granites of Egypt. J. Volcan. and Geotherm.1 Res., 14, 187-198.

IAEG, (1981); Rock and soil descriptions for engineering geological mapping. Report by the IAEG Commission on Engineering Geological Mapping. Bull. Int. Assoc. Eng. Geol., 24, 235-274.

Irfan, T. Y., (1996): Mineralogy, fabric properties and classification of weathered granites in Hong Kong, Quart. J. Engineer. Geol \& Hydrogeol., 29, 5-35

Irfan, T. Y. and Dearman, W. R., (1978a): The engineering petrography of a weathered granite in Cornwall, England. Quart. J. Engineer. Geol., 11, 233-244

Irfan, T. Y. and Dearman, W. R., (1978b): Engineering classificational and index properties of a weathered granite, Bull. Inter. Assoc. Engineer. Geol., 32, 67-80.

Irfan, T. Y. and Powell, G. E., (1985): Engineering geological investigations for foundations on a deeply weathered granitic rock in Hong Kong. Bull. Int. Assoc. Eng. Geol., 32, 67-80.

ISRM, (1981): Basic geotechnical description of rock masses. Int. Soc. for Rock Mech., Commission on Standardization of Laboratory and Field Tests. Int. J. Rock Mech. Min. Sci. Geomech. Abstr., 18, 85-110.

Kilic, R., (1995): Geomechanical properties of the ophiolites (Çankırı, TURKEY) and alteration degree of diabase. Bull. Int. Assoc. Eng. Geol., 51, 63-69

Lan, H. X., Hu, R. L., Yue, Z. Q., Lee, C. F. and Wang, S. J., (2003): Engineering and geological characteristics of granite weathering profiles in South China. J. Asian Earth Sci., 21, 353- 364.

Le Maitre, R. W., Bateman, P., Dudek, A., Keller, J. Lameyre, LeBase, M. J., Sabine, P. A., Schmid, R., Sorensen, H. Streckeisen, A., Woolley, A. R. and Zanettin, B., (1989): A classification of igneous rocks and glossary of terms. Blackwell, Oxford.

Lee, S. G., (1987): Weathering and geotechnical characterization of Korean granites. Ph. D. thesis, Imperial College, University of London.

Nesbitt, H. W. and Young, G. M., (1982): Early Proterozoic climates and plate motions inferred from major element chemistry of lutites. Nature, 299, 715-717

Nesbitt, H. W. and Young, G. M., (1984): Prediction of some weathering trends of plutonic and volcanic rocks based on thermodynamic and kinetic considerations. Geochim. et Cosmochim. Acta, 48(7), 15231534

Onodera, T. F., Yoshinaka, R. and Oda, M., (1974): Weathering and its relation to mechanical properties of granite. Third International Conference of ISRM, Denver 2A, 71-78.

Pearce, J. A., Harris, N. B. W. and Tindle, A. G., (1984): Trace element discrimination diagrams for the tectonic interpretation of granitic rocks, J. Petrol., 25, 956-983.

Raj, J. K., (1985): Characterization of weathering profile developed over a porphyritic biotite granite in Peninsula Malaysia. Bulletin of the International Association of Engineering Geology, 232, 121-130.

Rickwood, P. C., (1989): Boundary lines within petrologic diagrams which use oxides of major and minor elements. Lithos, 22, 247-263.

Sabet, A. H., (1972): On the stratigraphy of the basement rocks of Egypt. Ann. Geol. Surv. Egypt. II, 79-101.

Salem, A. K. A., Kabesh, M. L. and Salem, M. A., (1995): Petrochemistry, geochemistry and tectonic setting of the granitic rocks of Biririg Pluton, Eastern Desert, Egypt. Bull. N R C, Egypt, 20(2), 201-224.

Selvaraj, K. and Arthur, C. T., (2006): Moderate chemical weathering of subtropical Taiwan: Constraints from solid phase geochemistry of sediments and sedimentary rocks. J. Geol., 2006, 114, 101-116. 
Shand, S. J., (1947): The Eruptive Rocks. 3rd. New York, John Wiley; 444 p.

Sousa, L. M. O., Suarez, del Rio, L. M., Calleja, L., Vicente, G., Argandofia, V. G. R. and Rey, A. R., (2005): Influence of microfractures and porosity on the physico-mechanical properties and weathering of ornamental granites. Engineer. Geol., 77, 153-168.

Stern, R. J., (1979): Late Precambrian Ensimatic Volcanism in the Central Eastern Desert of Egypt. Ph.D Thesis, University of California, San Diego.

Stern, R. J., Gottfried, D. and Hedge, C. E., (1984): Late Precambrian rifting and crustal evolution in theNorth Eastern Desert of Egypt. Geology, 12, 168-172.

Sun, S. S., (1982): Chemical composition and origin of the earth's primitive mantle. Geochim. Cosmochim. Acta, 46, 179-192.

Thompson, R. N., (1982): Magmatism of the British Tertiary volcanic province. Scott. J. Geol., 18, 49- 107.

Thronton, C. P. and Tuttle, O. F. (1960): Chemistry of Igneous. Part I: Differentiation index. Amer. J. Sci., 258, 664-684

Tuğrul, A. and Gurpınar, O., (1997): The effect of chemical weathering on the engineering properties of Eocene basalts in northeastern Turkey. Environ. \& Engineer. Geosci., 3, 225-234.

Whalen, J. B., Currie, K. L. and Chappell, B.W., (1987): A-type granites: geochemical characteristics, discrimination and petrogenesis. Contrib Mineral Petrol., 95, 407-419.

Zen, E., (1988): Phase relations of peraluminous granitic rocks and their petrogenetic implications. Annual Review of Earth \& Planet. Sci., 16, 21-52. 
Discrimination of less and high fractionated granitic rocks

تمييز صخور الجرانيت المنخفضة والعالية التفارق بواسطة مخطط التجوية، منطقة بريريج، وسط الصحراء الثرقية، مصر

\author{
عبد الكريم أحمد سالم، باسل شلبى، وائل عبدالوهاب، على اسماعيل \\ قسم العلوم الجيولوجية، المركز القومى للبحوث، شارع البحوث، الاقى، الجيزه، مصر \\ الخلاصة
}

يتتاول البحث الصخور الجرانيتية بمنطقة بريريج وتقسيمها اعتمادا على التركيب المعدنى والكيمبائى، كما يناقش البحث تأثنرعمليات التجوية على التركيب المعدنى. وقد أظهرت الدراسة الجيوكيميائية أن صخور الجرانيت فى منطقة بريريج قد نشأت التئي من صهير كالسى قلوى ألومينيومى وذلك طبقا لمؤشر أجبيتيك والمؤشر القلوى الجيرى المعدل ومؤشر التشيع الألومينيومى. وبناء على الخصائص الجيوكيميائية فقد نم تقسيم الصخور الجرانيتية بمنطقة بريريج الى جرانيت أبيض وردى منخفض التفارق

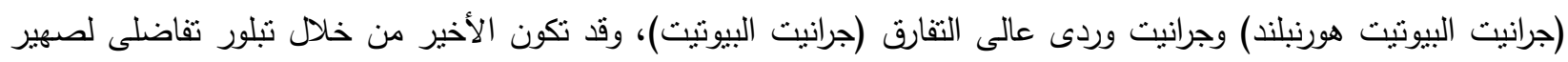
قاعدى كالسى ـ كما أظهرت الدراسة أن الجرانيت فى منطقة بريريج قد تكون فى بيئة الحواف القارية النشطة حيث أظئ أظهرت

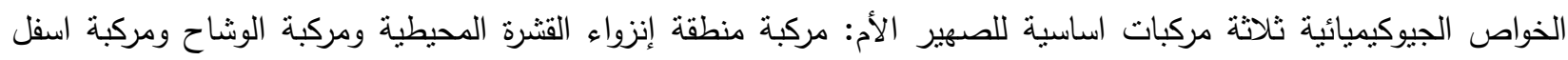
القشرة القارية. وقد تتاول البحث ايضا دراسة العلاقة بين مسنويات التجوية، لصخور الجرانيت محل الدراسة، وتأثيرها على الخواص الهندسية (الفيزيقية والميكانيكية). وقد تم الإسنعانة بالمؤشر الكيميائى للتغييروالذى أظهر أن صخور جرانيت بريريج قد تأثرت بمسنويات

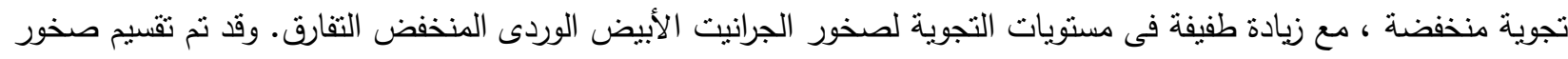

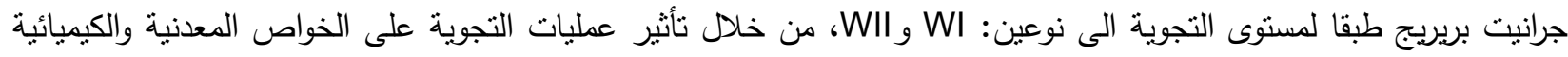

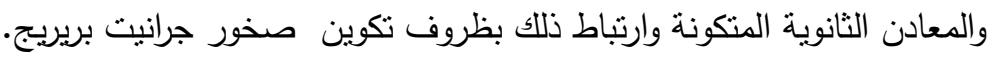

